\title{
Gowing grain for others or HOW TO DETECT SURPLUS PRODUCTION?
}

\author{
Corrie Bakels
}

\section{INTRODUCTION}

The production of surpluses of food, especially of staple food, is one of the pillars of a stratified society, both now and in the past. Also, it is the conditio sine qua non for the existence of full-time artisans and other non-food producers. When social stratification is found in the archaeological record, it is immediately deduced that the surplus of food was present. It goes without saying that it must have been, but ... can we really prove surplus production directly?

I envisage four possible approaches:

1. calculation of local production shows production to exceed local consumption;

2. analysis of local products shows them to favour one dominant product;

3. the presence of excessive storage capacity undoubtedly reveals connections with surpluses;

4. the presence of imported goods generally implies the production of a surplus elsewhere.

In the following, examples of such approaches will be given. I will take these from western Europe and its main staple-food, grain, because these are the cases I am familiar with. The choice does not imply that the considerations cannot be applied to other parts of the world.

\section{LOCAL PRODUCTION VERSUS LOCAL CONSUMPTION}

The first approach is comparing local consumption and local production. If the farmers consume their own products, there is no surplus. Calculations of this kind are becoming more and more popular. They are based on four parameters:

1. the number of producers;

2. the daily food intake of the producers;

3. the amount of arable land;

4. the net yield of arable land.

My first example concerns a complex of Celtic fields. The term refers to a system of rectangular fields of broadly Iron Age date which was rather common in England, the Netherlands, northern Germany, and Denmark. The system in question lies near 
Vaassen, the Netherlands. It consists of eight sets of fields. Each set is divided in two or three subsets. This subdivision is generally explained by the practice of having crop-producing years followed by fallow years. The complex covers 16 hectares, half of which would have been actually productive at one and the same time. It is thought to be connected with two farms, which might have been inhabited by 15 persons altogether (Brongers 1972). According to our general assumptions, their food intake should amount to $12,227,500 \mathrm{Kcal} /$ year (Gregg 1988; Fokkens 1991). If $80 \%$ of their energy requirements were satisfied by grain, and grain provided 3,100 Kcal/kg, these people consumed $3,155 \mathrm{~kg}$ grain/year.

The grain was provided by their own harvest. It is not unreasonable to set the gross yield at $1,000 \mathrm{~kg} /$ hectare. If $200 \mathrm{~kg}$ of sowing grain is subtracted, the net yield amounts to $800 \mathrm{~kg}$. With eight producing hectares, this is a net yield of 6,400 $\mathrm{kg} /$ year. The result is $3,245 \mathrm{~kg}$ of surplus grain, a happy outcome, because these Iron Age societies show some social differentiation.

Still, caution is needed. There are four main parameters, the values of which are guesstimates. If one of them changes, the outcome changes and the surplus may vanish entirely. If the families numbered 30 instead of 15, the surplus is gone. If the gross yield was only $600 \mathrm{~kg} /$ hectare, the surplus is gone too. If part of the eight hectares was used to grow food-plants less rich in calories, or, if fallow was not practised every other year but after two subsequent years of harvest, the surplus is quite different from the one calculated above. Clearly, this approach should use a series of calculations with the parameters set at their probable minimum and maximum values.

Another example of this kind of reckoning, now the other way round, are the calculations published by A. Kreuz (1994/95) concerning the feeding of the Roman army in the Wetterau region, Germany. In the year AD 165, this army comprised 8,312 men, 2,121 horses, and 976 pack-animals, all of which had to live on the land. Each soldier was entitled to $1 \mathrm{~kg}$ grain a day. The 8,312 men needed $3033.9 \mathrm{t} /$ year. The net yield of a hectare of arable land is set at $800 \mathrm{~kg}$ and the ratio of sowing seed : crop is estimated at 1:10. It follows that, for the soldiers' grain alone, 4,171.4 productive hectares were needed. If one allows for crops alternating with fallow, the surface is doubled to 8,343 hectares.

I shall refrain from citing more calculations but the grain could have been produced by 910 labourers aided by 455 oxen. Because these people also had to eat, the total area needed for grain growing amounted to $91 \mathrm{~km}^{2}$.

For producing fodder, some $52 \mathrm{~km}^{2}$ more were needed. As the Wetterau region is $750 \mathrm{~km}^{2}$ large, some $19 \%$ of its total surface should have been used to produce the surplus required for the army. This seems feasible. The area included a minimum of 250 large farms. In the Roman villa system, these should have been able to provide the extra labour. The surplus required by the army of occupation should not have caused any problems.

\section{Monoculture}

Surpluses that really matter are never obtained on all fronts. Most farmers are suc- 
cessful in one kind of product. This implies that surplus production can be detected by the demonstration of monoculture. People who farm for their own subsistence alone grow a wide spectrum of crops, unless the climate does not permit this practice.

Wide-spectrum farming versus a production biased towards one crop should be visible in the archaeobotanical record of a site. This possibility is limited, of course, by the chances of preservation. In the case of cereal remains, it is an option, because cereal remains belong to the class of plant remains that has a reasonable possibility of surviving.

Monoculture cannot be concluded on the basis of a single find, not even when this is in a beautifully preserved state. In such cases, chance plays too important a rôle. A dominant crop shows as the most common member of all crop-plant assemblages found everywhere on the farm, agricultural waste included. This may be calculated in numbers, or, when remains are scarce, in frequency. I shall apply this line of reasoning in two cases.

The first case concerns a set of farms comparable with those at Vaassen, because from Vaassen itself no archaeobotanical remains have been recovered. I will use those obtained in the large-scale excavations at Oss-Ussen, the Netherlands, instead.

The middle Iron Age farms at Oss-Ussen have not revealed any large concentration of grain. A scatter of carbonised kernels and chaff remains is found, however, in the traces of farm houses, granaries, and pits. Barley is present in $50 \%$ of the samples, emmer wheat in $38 \%$, and millet in $25 \%$. In the wells, with their waterlogged material, barley amounts to $67 \%$, emmer wheat to $44 \%$, millet to $33 \%$ whilst a second wheat species, spelt, is present with $33 \%$ too. Spelt wheat is represented by its well identifiable chaff, and chaff is commonly well preserved under waterlogged conditions.

In the late Iron Age the frequencies are comparable. No dominance of one single species occurs. This is supported by the analyses of impressions in pottery. All grain types are there, which implies that no cereal dominated amongst the grain lying scattered in the farm yards (Bakels 1994a). Vaassen and Oss-Ussen type farmers did not practice monoculture.

My second case is a large Roman villa at Voerendaal, the Netherlands. Its yard with granary, outhouses etc. has been intensively sampled for seeds. Remains of spelt wheat dominate both in numbers and in frequency. Its frequency amounts to nearly $100 \%$. It is clear that the farm specialised in the growing of spelt wheat (Kooistra 1991). As Voerendaal is situated in a region very well suited to agriculture, this was a choice, not a dictate by environmental factors. Since it is well-known that Roman villas did grow grain for selling, this evidence for specialisation does not come as a surprise.

\section{STORAGE CAPACITY}

Surpluses of staple products have to be stored somewhere. Storage can take place at the producer site, at the consumer site, or at both. Grain can be stored in granaries, in underground silos or in lofts. Storage space that surpasses the need of a farm in- 
dicates local surplus production. Excess storage space, mostly centralised, in an evidently non-producer site indicates the creation of surplus elsewhere. Things become difficult if the staple food was distributed immediately on arrival among consumer households. I shall restrict my examples to the producer side of the economy, and shall start, once again, with the Iron Age farms referred to above.

At Oss-Ussen, each farm house is accompanied by one, two or perhaps three socalled granaries. These are small buildings supposed to have had a floor well raised above the surface, supported by four, six or nine stout posts. Their interpretation as granaries, or, more generally, as storage rooms is mainly based on ethnographic parallels. If these buildings were indeed the places were the crop was stored, we need to know their storage capacity.

In excavations, only the traces of the posts are found. These give an indication of the size of of the floor space. It is the only parameter that can be measured with some accuracy; the others are conjecture. Unknown, for instance, is how the grain was stored. Unthreshed with straw, partly threshed, threshed? From the rare cases in which burnt stocks were found, it can be deduced that the barleys, wheats, and millets stored in Oss-Ussen type granaries were stocked without their straw but still covered by their husks (Matterne-Zech 1996). Was the grain stored in bulk or stored in sacks or baskets? Most people who have been calculating storage capacities started from bulk storage. Some recent excavations of burnt-down granaries have shown, however, that this is far from sure (Bakels 1994b; Henriksen and Robinson 1996; Matterne-Zech 1996). If in bulk, how high could the grain be piled up? Was it a heap or an even layer confined by upright walls?

If I take a granary with a floor space of $5 \mathrm{~m}^{2}$, a normal size, and I opt for bulk storage one metre high within walls, the storage capacity is $5 \mathrm{~m}^{3}$, or approximately 4,500 $\mathrm{kg}$, and more than one single farmer's family needs, if the calculations presented above are followed. In Vaassen, a net yield of $3,155 \mathrm{~kg}$ or a gross yield of $4,755 \mathrm{~kg}$ was needed for two families. Still, this calculation cannot be used to prove surplus cultivation. First, the storage capacity must be substantially reduced, perhaps even halved, if sacks were used. In that case, the surplus vanishes. This outcome can be counteracted by assuming that each farm possessed two granaries instead of one. The excavated farm yards show indeed the presence of more granaries than main buildings. Still, it is by no means sure that a granary stood as long as a farm. Moreover, not all storage is grain storage.

It is clear that this approach of surplus analysis has many pitfalls. Nevertheless, the presence of many small granaries in one site may point to surplus storage. The best examples are found, however, not in producer sites but in redistribution sites such as the Iron Age hillfort of Danebury, England (Jones, M. 1984).

Roman villas had much larger buildings for grain storage - the so-called horrea. The horreum at Voerendaal had a floor space of $384 \mathrm{~m}^{2}$. There are good indications that in this kind of buildings grain was not stored in bulk but in some sort of containers (Pals, Beemster, and Noordam 1989) and the capacity might not have been as large as might be thought. Nevertheless, even then, the horreum is so big that its size must have by far and away exceeded local needs. 


\section{IMPORTS}

Import of grain implies the existence of surplus growing for export elsewhere. The analysis is carried out at consumer sites. Grain must be imported if it cannot be produced by the consumer. Clear cases are long-distance transports of cereals which cannot have been grown locally because of climatological reasons, such as rice in north-western Europe. Even if the grain itself does not reveal its status, the accompanying weeds can betray the foreign origin.

A good case is a Roman ship with a cargo of grain found on the bottom of the river Rhine near the Dutch town of Woerden. It contained emmer wheat, a cereal which could have been produced by the local population but for the weed flora. The weeds points towards a more southerly origin, even if we allow for better climatological conditions during the Roman period. The nearest possible region is the villa belt of the German Rhineland, the southernmost tip of the Netherlands, and Belgium (Pals and Hakbijl 1992).

Another example concerns also ships, sixteenth century ones in this case. Two ships, wrecked near the Dutch island of Texel and bound for Amsterdam, had cargos of wheat mixed with an eastern European weed flora (Manders 1993). As it is known from written sources that most of these wheats came from the Baltic or Poland, this was a nice independent check upon the botanical results.

\section{CONCLUSIONS}

I chose my examples, as far as possible, from two contexts, the middle or late Iron Age farm connected with the Celtic field system, and the Roman villa system.

According to the surface of arable land, the Iron Age farms could have produced a surplus. Their granaries were spacious enough to store this surplus. But, if minimum values for the various parameters are used, the surplus disappears. The impression given by the first and third kind of approach is that surplus production, if present, cannot have been a large-scale affair. This view is strenghtened by the result of the second approach: no grain species seems to have been dominant over the others.

The Roman villa system was well able to provide the Roman army of occupation with its daily rations. The second approach revealed the existence of monoculture and the third one the presence of ample storage capacity. In this case, all three approaches point towards the growing of substantial surpluses. The fourth approach showed the export of the product, a fact already known from written sources.

All approaches have their problems and not one of them provides clear-cut results. But, taken together, the results do not contradict each other. A combination may indeed give some 'proof' of surplus growing, as far as 'proofs' can be given in archaeology.

\section{FUTURE PROSPECTS}

The existence of ways to detect surplus cultivation and even its extent creates the possibility of studying the practice in its own right and to write a history of surplus 
production. Up till now, only a limited number of case studies is available. Attempts at giving a diachronic picture have not yet come to my attention. Obvious questions to be tackled include the classic 'where', 'when', and 'why' questions.

I understand surplus cultivation to be the intentional creation of a surplus in order to obtain material or immaterial valuables produced by others. Every food producer will try to produce extra yields as a buffer for a bad year to follow. If this reserve is not needed, it will be used to obtain something else, instead of being left to rot. Such instances have nothing to do with surplus cultivation because the crops were not grown for the prupose. Only if the unused reserves become structural can this buffer develop into surplus. I stress this possibility, because the producer can also decide to reduce her/his output. A detailed study could reveal where and when this step was taken. Such a development would not necessarily have been a unilocal affair.

It is my surmise that the production of food which can be stored for a long time, combined with a sedentary way of life, offer the best conditions for incipient surplus cultivation. When societies are already based upon surplus production, these conditions lose their importance. Perishable products, for instance, can find customers in a developed, or stratified society. The required conditions may be found in certain hunter-gatherer societies but may have been commonest in grain-growing societies, especially those blessed with an optimum soil and climate. Environmental constraints may provide a check on such developments; such aspects can be studied.

Nevertheless, good environmental conditions do not explain why it is that people began to produce surpluses. A good reason may be the wish to procure goods not provided by domestic production, because they required exotic raw materials or specific skills. Demand may concern both material products, such as tools and luxury goods, or non-material goods, such as healing skill and magic. Related reasons may be related to social competition for power, prestige, and respect. Once established, surplus may have become indispensable, with societies becoming increasingly dependent upon it step by step. This route leads to social history.

The history of food economy and social history are closely intertwined. The aim of this article is to contribute to a better understanding of one of the strands - the economic strand, or the history of surplus production. When we understand this strand better, we can relate it more convincingly to the other strands of social history and the development of social stratification mentioned in the introduction. Many results will depend upon the inter-relationship between supply and demand - a chicken-and-egg situation in the case of causal analysis. But some surprises may yet be in store for us.

\section{BIBLIOGRAPHY}

BAKELS, CORRIE. C., 1994a. Vruchten en zaden uit de ijzertijd-nederzettingen te OssUssen. In K. Schinkel, Zwervende Erven: 219-232. Leiden University, PhD Thesis.

BAKELS, CORRIE, 1994b. Structure 61, Etude des macrorestes végétaux. In Jan Vanmoerkerke (ed.), Fouille de sauvetage à Goin - Aéroport Régional de Lorraine, zone $H$ ("Taxiway"): 34-36. Metz, Service régional de l'archéologie de Lorraine. 
BRONGERS, J. A., 1972. Vaassen, een akkercomplex uit de ijzertijd. Bussum (Archaeologische monumenten in Nederland 3).

FOKKENS, HARRY, 1991. Verdrinkend Landschap. Groningen University, Phd Thesis.

GREGG, S., 1988. Foragers and Farmers. Chicago: University of Chicago Press.

HENRIKSEN, P. S. and D. ROBINSON, 1996. Early Iron Age agriculture: archaeobotanical evidence from an underground granary at Overbygard in northern Jutland, Denmark. Vegetation History and Archaeobotany 5:1-11.

JONES, M. K., 1984. The plant remains. In B. Cunliffe (ed.), Danebury. An Iron Age hillfort in Hampshire, vol. 2, The Excavations, 1969-1978, The Finds: 483-495. London: Society of Antiquaries of London.

KootstRA, L. I., 1991. Arable farming in the hey day of the Roman villa at Voerendaal (Limburg, the Netherlands). Acta Interdisciplinaria Archaeologica 7:165-175.

KREUZ, A., 1994/95. Landwirtschaft und ihre ökologischen Grundlagen in den Jahrhunderten um Christi Geburt: zum Stand der naturwissenschaftlichen Untersuchungen in Hessen. Berichte der Komission für Archäologische Landesforschung in Hessen 3:59-91.

MANDERS, M., 1993. Twee graanschepen, een botanische studie van de lading. In $R$. Reinders and A. van Holk (eds), Scheepslading: 19-31. Groningen: Biologisch Archaeologisch Instituut.

MATTERNE-ZECH, V., 1996. A study of the carbonized seeds from a La Tène D1 rural settlement, "Le Camp du Roi" excavation at Jaux (Oise), France. Vegetation History and Archaeobotany 5:99-104.

PALS, J. P., V. BEemSTER and A. NOORDAM, 1989. Plant remains from the Roman castellum Praetorium Agrippinae near Valkenburg (prov. of Zuid-Holland). Dissertationes Botanicae 133:117-134.

PALS, J. P. and T. HAKBIJ, 1992. Weed and insect infestation of a grain cargo in a ship at the Roman fort of Laurium in Woerden (Province of Zuid-Holland). Review of Palaeobotany and Palynology 73:287-300.

\section{ABSTRACTS}

\section{Growing grain for others or how to detect surplus production?}

The paper describes four characteristics by which surplus growing of grain might be detected: 1 . the calculated local production exceeded the calculated local consumption; 2 . farmers practised monoculture; 3 . storage capacity surpassed local needs; 4 . grain was clearly produced elsewhere and represented the import of a surplus.

Examples are given concerning Iron Age farms and Roman villa's in the Netherlands and comparable regions. Although each approach brings its own problems, a combination gives encouraging results. The analysis provides a tool for the writing of a history of surplus production which, in its turn, can be related to social history.

\section{La croissance des céréales pour d'autres ou comment déceler une production excédentaire}

L'article décrit quatre caractéristiques par lesquelles une croissance excédentaire de céréales pourrait être décelée. 1. Une évaluation de la production locale dépassant la consommation locale. 2 . Les agriculteurs pratiquant la monoculture. 3 . Une capacité de stockage dépassant la demande locale. 4. Les céreales mainfestement cultivés ailleurs représentant une importation excédentaire.

Les exemples donnés concernent les fermes à l'Age de Fer et les maisons romaines aux Pays-Bas et des regions comparables. Cependant, chaque approche entraine un problème propre, et une combinaison donne des résultats encourageants. L'analyse fournit un instrument de travail pour écrire l'histoire d'une production excédentaire, qui en fait peut être reliée à l'histoire sociale. 


\section{JOURNAL \\ EUROPEA N ARCHAEOLOGY}

JOURNAL OF THE EUROPEAN ASSOCIATION OF ARCHAEOLOGISTS

VOLUME 4

1996

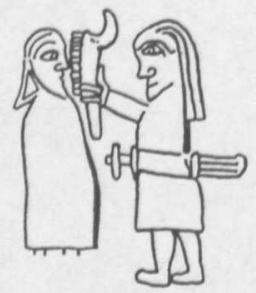

Cruithne Press

G L A S G O W 